\title{
Cost and time analysis of graving dock project
}

\author{
Silvianita ${ }^{1,}$, Nur Aprillia ${ }^{2}$, Yeyes Mulyadi ${ }^{1}$, Wahyudi Citrosiswoyo ${ }^{1}$, Suntoyo $^{1}$ \\ ${ }^{1}$ Ocean Engineering Department, Faculty of Marine Technology, Institut Teknologi Sepuluh \\ Nopember, Surabaya, Indonesia \\ ${ }^{2}$ Graduate Student, Ocean Engineering Department, Faculty of Marine Technology, Institut Teknologi \\ Sepuluh Nopember, Surabaya, Indonesia
}

\begin{abstract}
The construction of new shipyard in the Cilacap area is one of the best ways to reduce the accumulation of vessels. The construction of shipyard has many risks, one of the risks that can occur during the construction of the shipyard is in terms of cost and time. Project scheduling is a tool to make sure the project finished on time. This paper discusses project scheduling and cost calculation using Critical Path Method (CPM) and Program Evaluation Review Technique (PERT) method for Graving Dock project development in Cilacap. Project scheduling is useful to indicate the relation of each activity to another. This paper will discuss the critical activities during Gravity Dock development and the duration for the whole project using CPM. The next step is to determine the probability of the completing project that can be finished within the time frame using PERT. Based on the CPM analysis, the probability of Graving Dock project can be finished in 204 days is $79,81 \%$. The total cost for Graving Dock project in Cilacap is Rp. 6.486.122.769.
\end{abstract}

\section{Introduction}

Indonesia is the largest archipelagic country in the world which has the largest maritime area three times than its land area or close to $70 \%$ of the total country of Indonesia. Therefore the marine territory of Indonesia can be utilized as much as possible with a lot of potential to have a maritime industry and a large and powerful shipyard.

A shipyard is a place used for making and repairing a ship [1]. Great shipbuilding production in shipyard can be achieved by good internal communication and coordination and also understand of modern shipbuilding requirements and characters by shipyard company. Before undertaking a production scheduling process, firstly it would be better to carry out a survey to investigate the situation and condition of the shipyard namely human resources, information systems, shipbuilding technology, raw material procurement and shipyard operation [2].

The project is an activity with a certain allocation of resources and purpose to carry out tasks with limited time whose targets have been clearly outlined [3]. Project are generally limited by time and cost [2]. The success or failure of a project is often caused due to fail of coordination so that the activities become not efficient [4]. Those matters could lead the delay of the project completion. Project scheduling is very important to make sure the

\footnotetext{
*Corresponding Author : $\underline{\text { silvianita@oe.its.ac.id }}$
} 
project can run smoothly [5] and the application of project scheduling in various shipyard has been carried out [6-8]. Currently there are many new shipyards have been constructed in order to distinguish themselves from and to produce system innovations [9]. The project required a network planning to match the scheduling of time and cost that have been determined in order to make sure the project is on schedule and there is no additional time and cost [10].

Network planning will be useful to manage the project within the time frame. If there is any delay, it will affect the duration of the project and the budget that is not in accordance with the contract [11]. The shipyard development project aims to repair or maintain tug boat, vessel owned by government, private company etc operating in Cilacap area. Since the shipyard in Cilacap still very few therefore it is needed for consideration of the new development of shipyard to do repair and maintenance of the vessel.

\section{Methodologies}

The methodologies used in this paper are generated based on CPM and PERT method. The objectives of this paper namely determine the duration, cost and also the probability of developing Graving Dock can be finished on time.

\subsection{Data Collection}

Data collection used in this paper is based on shipbuilding project namely:

- Data duration schedule of project work

- Data job volume

\subsection{Project Scheduling Using CPM Method}

Project Scheduling using the CPM method is a network analysis facility that seeks to optimize project cost through reduction or acceleration of project completion time. This stage begins by making the network of work breakdown structure based on the data obtained. Then determine the critical path by performing forward calculations, backward calculation and calculating the total float so that the critical path can be identified and the total duration obtained.

\subsection{Probability of Project Finish on Time}

In order to identify the probability of project can be finished on time then PERT is used. PERT is useful to plan the project and to minimize the delay, as well as disruption of production and coordinate various parts of a job as a whole and accelerate the completion of the project. The PERT technique generates a controlled and orderly job because the schedule and budget of a job are predetermined before the project takes place.

\subsection{Project Cost Analysis}

After conducting analysis by using CPM method, then it can be seen the total duration of the project from the duration of the critical path. Cost is one of the things that must be prepared because it is needed as a guide in project implementation.

\section{Results and Discussion}

\subsection{Project Planning}

Construction project development Graving Dock in Tanjung Intan, Cilacap is a project organized by one of the shipyard company in Cilacap. This project takes 204 days work time from 12 January 2018 until 31 July 2018.

The project starts by planning the time and cost required for graving dock, and continues with the activity that needs to be done during the time frame. The estimation duration of each activity in graving dock can be based on the previous project experience. 


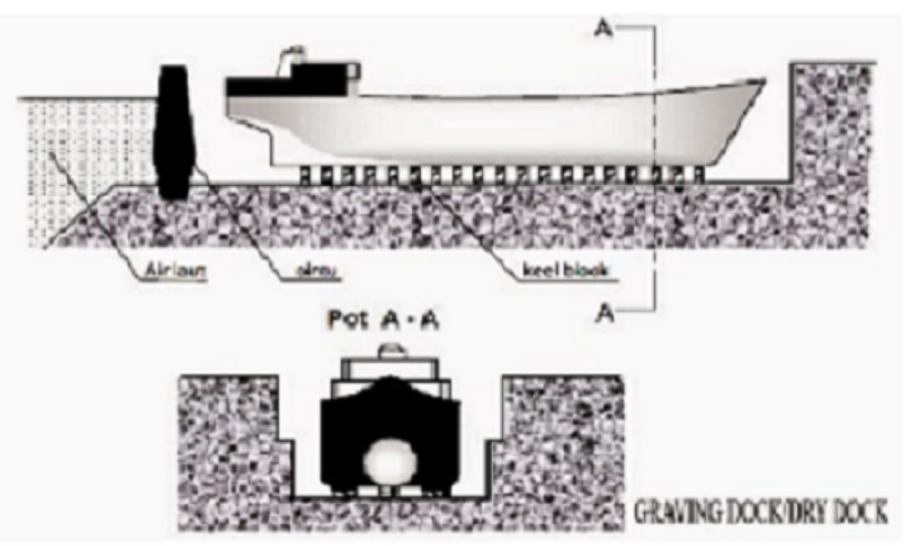

Fig 1. Graving Dock

\subsection{Scheduling Use Critical Path Method}

This stage begins with network planning to schedule the activity using CPM (Critical Path Method) based on WBS data. Figure 2 shows the network planning for this project:

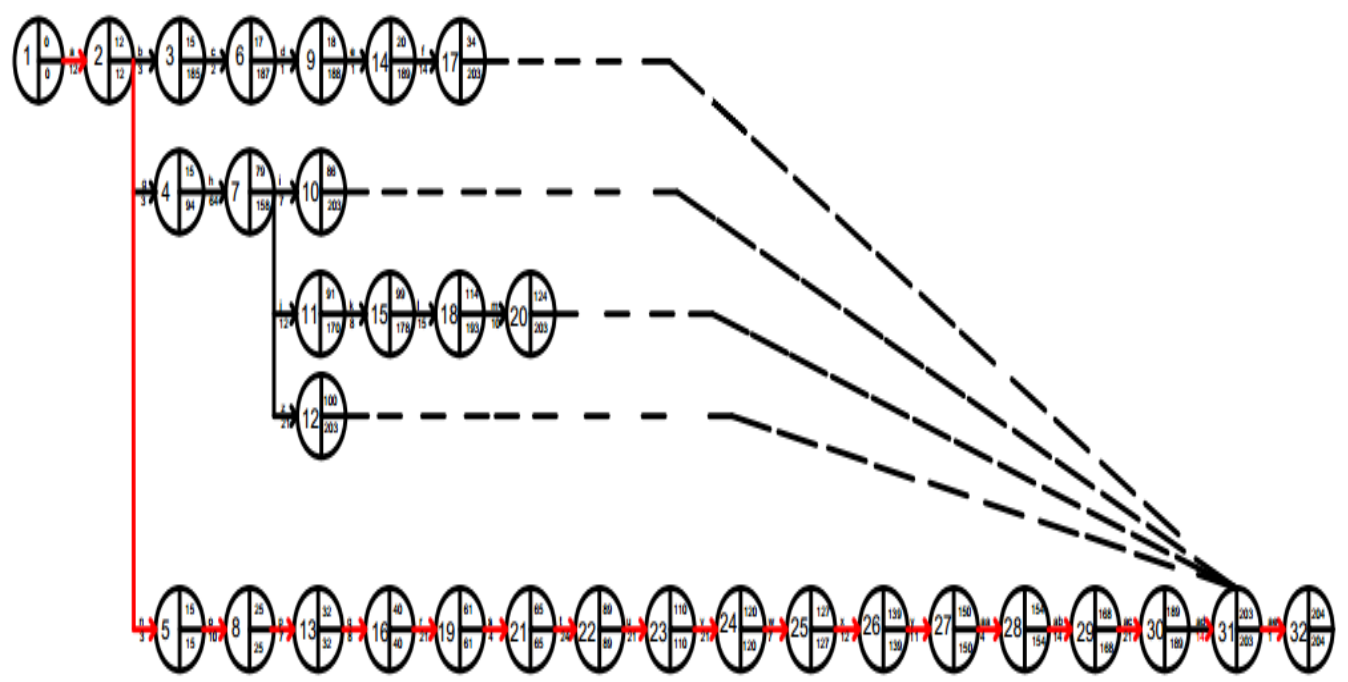

Fig 2 .Network Planning CPM

Based on network planning CPM, it was found that the length of duration required to complete the project was 204 days. Based on the Fig 2. the red line is a critical activity.

\subsection{Scheduling use Program Evaluation Review Technique Method}

Scheduling using PERT method is divided into several steps as follows [5]:

- 3 estimation times

This stage estimates 3 times duration of activity namely optimistic time (a), optimistic time (b) and most likely time (m).

- Calculate expected time, standard deviation and variance on the critical path.

Besides determining the above three times, the next step is to calculate the expected time, standard deviation and variance to determine the expected time by using the formula: 


$$
\begin{aligned}
& t e=\frac{a+4 m+b}{6} \\
& S=\frac{b-a}{6} \\
& V(t e)=S^{2}
\end{aligned}
$$

- Calculate the probability of project completion after obtaining the expected time, standard deviation and variance on some critical activities can be continued by calculating the normal $\mathrm{z}$-value. The normal $\mathrm{z}$-value is useful to determine the probability of the completed project within the time frame using normal distribution.

$$
\begin{gathered}
Z=\frac{T_{d}}{t_{e}} \\
Z=\frac{210-204}{11,3} \\
Z=0,53
\end{gathered}
$$

Td is the duration of the project based on the contract which is 210 days. Based on table of normal distribution of cumulative with value of $Z=0,53$, the possibility of the project to be completed within 204 days is $79,81 \%$.

\subsection{Project Cost Planning Data}

The implementation of a cost project is important things that must be prepared because it is needed as a guide in project implementation.

There are 2 types of cost in a project namely Direct Cost and Indirect Cost.

1. Direct costs are the cost directly related to the construction of the field. This direct cost is obtained from the multiplication of the volume of job and the unit price of the work. Details of the direct cost of the development graving dock project can be seen in table 1 below:

Table 1. Direct Cost

\begin{tabular}{|l|l|r|c|c|}
\hline No. & \multicolumn{1}{|c|}{ Activities } & Total Cost (IDR) & Code & $\begin{array}{c}\text { Duration } \\
\text { (Days) }\end{array}$ \\
\hline I. $\quad$ Preparation Work & $95.400,00$ & A & 12 \\
\hline 1 & Land Clearing & $147.070,00$ & B & 3 \\
\hline 2 & Measurement \& Bouwplank & $2.294 .857,00$ & C & 2 \\
\hline 3 & Keet Direction \& Temporary Facility & $210.000 .000,00$ & D & 1 \\
\hline 4 & Shop Drawing \& Site Engineering & $471.493 .788,00$ & E & 1 \\
\hline 5 & Mobilization & $242.780 .786,00$ & F & 14 \\
\hline 6 & Damage of Sea Water & $47.624 .227,20$ & G & 3 \\
\hline II. & Concrete Sheet Pile Work \& Concrete Wall & $156.121 .700,00$ & H & 64 \\
\hline 7 & Procurement of Concrete Sheet Pile & $220.199 .057,46$ & I & 7 \\
\hline 8 & Service for Erection Concrete Sheet Pile & & \\
\hline 9 & Treatment Concrete Sheet Pile & $284.680 .168,00$ & J & 12 \\
\hline III. $\quad$ Excavation Work Ground Area of Graving Dock \\
\hline 10 & Excavation Work Area Graving Dock & \multicolumn{5}{|c|}{} \\
\hline
\end{tabular}




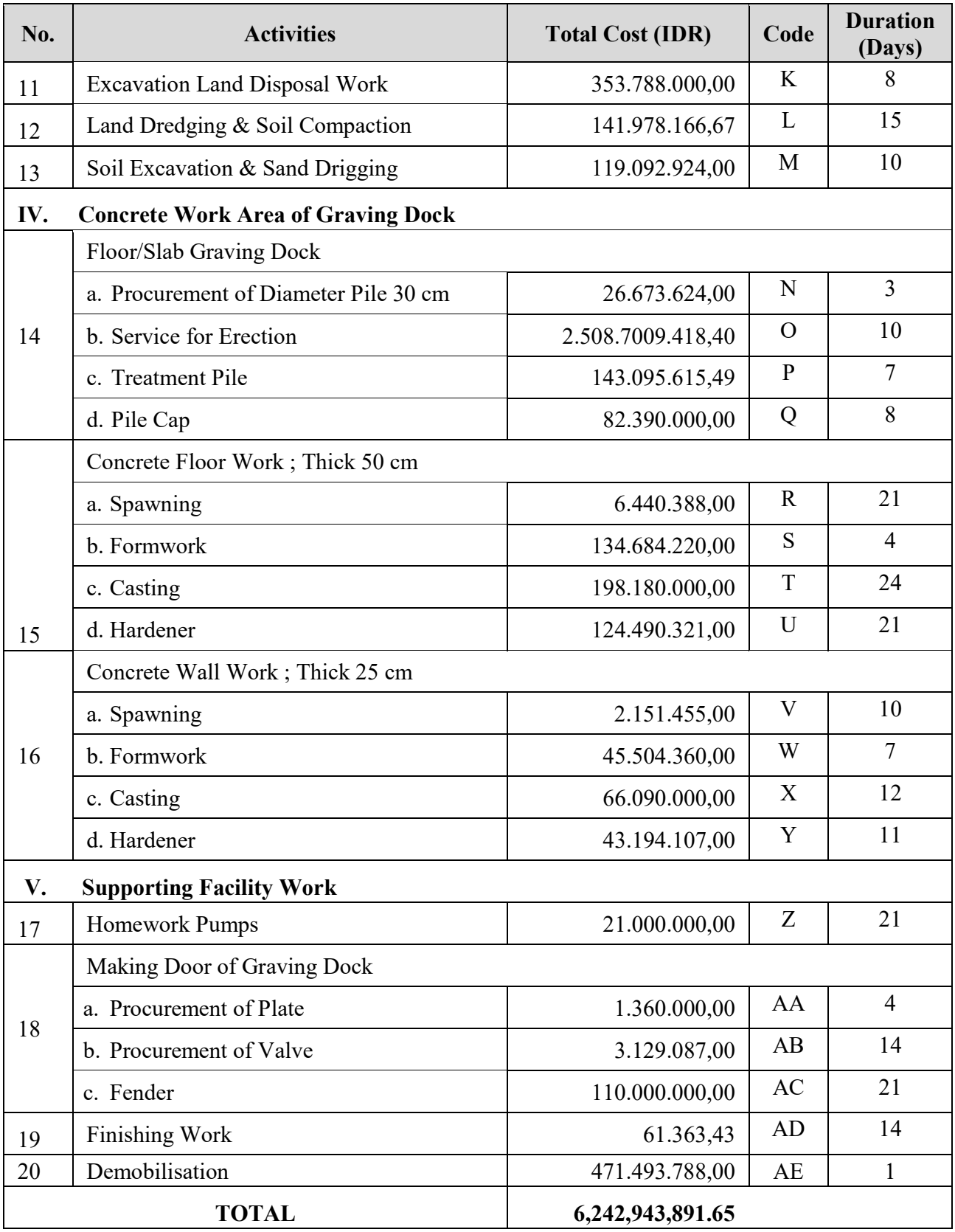

2. Indirect costs are costs that are not directly related to production namely overhead cost and unforeseen expenses. Indirect cost is often called distributed cost. Indirect cost may include the cost of any labor that is supportive of the production process. Detail of indirect cost of development graving dock can be seen in table 2 below: 
Table 2. Indirect Cost

\begin{tabular}{|l|l|r|}
\hline No & Job Description & Total Cost (IDR) \\
\hline \multicolumn{2}{|l|}{ I. Overhead Cost } & 33.660 .000 \\
\hline \multicolumn{2}{|l|}{ 1. Salary of Proyek Staff } \\
\hline a $\quad$ Site Manager & 21.420 .000 \\
\hline b & Civilian Executive & 13.260 .000 \\
\hline c & Logistik & 19.380 .000 \\
\hline d & Administration & 30.600 .000 \\
\hline 2. Facility (call, electricity, water, transportation) & 624.294 .389 \\
\hline II. Unforeseen Expenses (10\% of real cost) & 520.245 \\
\hline \multicolumn{2}{|l|}{ Unforeseen Expenses every day } & $\mathbf{7 4 2 . 6 1 4 . 3 8 9}$ \\
\hline
\end{tabular}

3. Duration of the project construction is one of the key parameter to indicate the success of a project. In order to determine the cost and duration relation therefore it is needed to make $\mathrm{S}$ Curve. S curve is used to indicate the progress of the project based on cost and time. Figure 3 shows the $\mathrm{S}$ Curve for this project.

\begin{tabular}{|c|l|r|r|c|c|c|c|c|c|}
\hline No & Activity & Total & Jan & Feb & Mar & Apr & May & Jun & Jul \\
\hline 1 & Preparation Work & $926.811 .901,00$ & & & & & & & \\
\hline 2 & Concrete Sheet Pile Work \& Concrete Wall & $423.944 .984,66$ & & & & & & & \\
\hline 3 & Excavation Work Ground Area of Graving Dock & $899.539 .258,67$ & & & & & & & \\
\hline 4 & Concrete Work Area of Graving Dock & $3.385 .603 .508,89$ & & & & & & & \\
\hline 5 & Supporting Facilities Work & $607.044 .283,43$ & & & & & & & \\
\hline & TOTAL & $6,242,943,891.65$ & $13 \%$ & $37 \%$ & $66 \%$ & $82 \%$ & $88 \%$ & $90 \%$ & $100 \%$ \\
\hline
\end{tabular}

Fig 3. S Curve.

\section{Conclusions}

Based on the analysis of project scheduling with CPM-PERT method for the development of Graving Dock in Tanjung Intan, Cilacap the following conclusions can be drawn:

1. The cost to develop Graving Dock in Tanjung Intan Cilacap is Rp. 6.985.558.280,65.

2. The critical activities in construction of Graving Dock project in Tanjung Intan is the activities with code A-N-O-P-Q-R-S-T-U-V-W-X-Y-AA-AB-AC-AD-AE and can be completed within 204 days.

3. Based on PERT calculation, it is found that the probability of the shipyard development project on the Tanjung Intan, Cilacap is completed within 204 days is $79,81 \%$. 4.

\section{References}

1. A. Wulandari, Analisa Peningkatan Kualitas Layanan Jasa Reparasi Kapal di Galangan Kapal Jawa Timur. 2016, Institut Teknologi Sepuluh Nopember: Surabaya. 
2. F.F. Clifford, Erik, W. L., Manajemen Proyek: Proses Manajerial. 2007: Andi Publisher, Yogyakarta.

3. M. Aulady, Orleans, C., Perbandingan Durasi Waktu Proyek Konstruksi Antara Metode Critical Path Method (CPM) dengan Metode Critical Chain Project Management (Studi Kasus: Proyek Pembangunan Apartemen Menara Rungkut). Jurnal IPTEK Institut Teknologi Adhi Tama, 2016. 20: p. 14-18.

4. A. N. Andr., Optimalisasi Penjadwalan Proyek pada Pembangunan Gedung Khusus Laboratorium Stasiun Karantina Ikan Kelas 1 Tanjung Emas Semarang. 2007, Universitas Negeri Semarang.

5. A. Arinto., Exploring Bar Chart Method, CPM, PDM, PERT, Line of Balance, and Time Chainage Diagram in Project Scheduling Construction. 2010, Diponegoro University: Semarang.

6. Silvianita., N., A., Mulyadi, Y., Suntoyo., Chamelia, D. M Project Scheduling Based on Risk of Gas Transmission Pipe. in IOP Conference Series: Earth and Environmental Science. 2018.

7. Silvianita., F., R., Rosyid, D. M., Suntoyo., Chamelia, D. M. Fast Missile Boat Project Planning using CPM and What If Analysis Method. in IOP Conference Series: Earth and Environmental Science. 2018.

8. Silvianita, A.N.S., Daniel M Rosyid. Project Delay Analysis of HRSG. 2017: IOP Conference Series: Earth and Environmental Science.

9. J. S. Young, J.H.W., Jong Gye Shin, Research on a Simulation Based Ship Production Support System for Middle Sized Shipbuilding Companies. International Journal Naval Architec Ocean Engineering, 2009. 1: p. 70-77.

10. D. Alfianto., Evaluasi Penjadwalan Proyek dengan Menggunakan Metode CPM dan Analisis Kurva S pada Proyek Studi Detail Desain Pantai Les Tejakula di Kab Buleleng Bali. 2012, Universitas Pembangunan Nasional Veteran.

11. H. Gitosudarmo., Indriyo, Sistem Perencanaan dan Pengendalian Produksi, ed. E. 2. 2000, Yogyakarta: BPFE UGM. 